\title{
Interaction Effects of Insecticides on Enzyme Activities in Black Clay Soil from Groundnut (Arachis hypogaea L.) Fields
}

\author{
C. Nasreen, G. Jaffer Mohiddin, M. Srinivasulu, A. Rekha Padmini, \\ P. Ramanamma and V. Rangaswamy \\ Department of Microbiology, Sri Krishnadevaraya University, India.
}

crossref $\mathrm{http} / / / \mathrm{dx}$. doi.org/10.5755/j01.erem.60.2.671

(received in November, 2011, accepted in June, 2012)

\begin{abstract}
In practice pesticides are extensively used in agriculture as a part of pest control strategies. Two insecticides, endosulfan (organochlorine) and profenophos (organophosphate), were assessed for their effects on the activities of protease (in terms of tyrosine formed from casein) and urease (as ammonia released from urea) in soil, collected from a fallow groundnut field by applications of insecticides at normal field rates and at higher concentrations $\left(1.0,2.5,5.0,7.5,10.0 \mathrm{~kg} \mathrm{ha}^{-1}\right)$, in a laboratory study. The results showed a strong positive influence on protease and urease enzyme activities in soil treated with 2.5 and $5.0 \mathrm{~kg} \mathrm{ha}^{-1}$ dry soil and they were significantly $(\mathrm{P} \leq 0.05)$ higher than the control over the course of incubation. In soil treatment, there was a significant increase in protease and decrease in urease activities after $24 \mathrm{~h}$ of incubation which continued up to 20 days. However, a significant decrease in both protease and urease enzyme activities was observed in 30 and 40 days of incubation.
\end{abstract}

Key words: Endosulfan, profenophos, soil enzymes, groundnut (Arachis hypogaea L.) soil.

\section{Introduction}

Since several decades, xenobiotic substances have been widely used in agriculture as a part of pest control strategies with the growing use of pesticides. The issue of an impact of these chemicals on the composition of soil microorganisms and the processes they direct have received more attention (Andrea et al. 2000, Baxter and Cummings 2008) and their background levels in the environment have increased greatly. As a consequence, these agrochemicals (biotoxicants) have been found in numerous natural systems and have a great impact on environment quality (Madhun and Freed 1990). Pesticides are developed and applied to destroy or suppress their only target organisms in agricultural crops; however, most often they also affect non-target organisms. Among the oil seeds and cash crops, the groundnut crop is frequently treated with pesticides. Groundnut (Arachis hypogaea L.) is one of the important major profitable crops grown in India throughout the year and is a world leader in groundnut farming, with eight million hectares of cultivated area in the year 20022003 (FAO 2004). The current productivity of groundnut in India is about quintal $(50 \mathrm{~kg})$ per ha (Talawar 2004). The present day agriculture involves abundant cultivation of the crop because of its vital role in edible oil seeds production (Kori et al. 2002). Groundnut ranks seventh among crops in terms of insecticide consumption in India (Giraddi et al. 1999). More than 120 pests affect economically important crops like groundnut, cotton, and tomato (Megharaj et al. 1999; Rangaswamy and Venkateswarlu 1992; Vijay Gundi et al. 2007; Jayashree and Vasudevan 2007; Romeh et al. 2009). When an anthropogenic factor is released deliberately or accidentally into the environment, about $0.1 \%$ of it reaches the target organism while the remaining $0.99 \%$ reaches the soil causing not only trouble to local metabolism or enzymatic activities (Carriger et al. 2006; Pimentel 1995 Engelen et al. 1998; Liu et al. 2008; Topp et al. 1997), but also disturbs the soil ecosystem and thus may affect human health by entering the food chain, and thus it has raised a considerable public concern.

Profenophos (0-4-bromo-2-chlorophenyl-Oethyl-S propylphosphorothioate) is a non systemic 
insecticide and acaricide with contact and stomach action used against mites, leafhoppers, thrips, aphids, mealy bugs and cotton stainers. Endosulfan is a chlorinated cyclodiene insecticide currently used throughout the world for the control of numerous insects in a wide variety of food and non food crops. Endosulfan has been ubiquitously detected in the atmosphere, soils, sediments, surface waters, rain waters and foodstuffs (Kwon et al. 2002). Endosulfan, due to its high degree of toxicity it persists in soils and water, has become an important group of contaminants. Although this pesticide has been restrictively used or even banned due to its persistence and bioaccumulation, it may be still found in soils. For this reason, soil biological responses to the pesticides are required to be estimated. To date, many efforts have been taken to understand the effect of pesticides on soil enzyme activities, protease urease, nevertheless little is known about the effect of endosulfan and profenophos. Proteases occur naturally in all organisms. Bacteria also secrete proteases to hydrolyse (digest) the peptide bonds in proteins and, therefore they break the proteins down into their constituent monomers. Urease (urea amidohydrolase, EC 3.5.1.5) is the enzyme that catalyses the hydrolysis of urea to $\mathrm{Co}_{2}$ and $\mathrm{NH}_{4}{ }^{+}$ions by acting on $\mathrm{C}-\mathrm{N}$ non - peptide bonds in linear amides. It is an important enzyme in soil that mediates the conversion of organic nitrogen to inorganic nitrogen by hydrolysis of urea to ammonia. The activities of these protease and urease enzymes are important in soil in releasing simple carbon and nitrogen sources for the growth and multiplication of soil microorganisms. Soil enzymes can be tracked as indicators of the soil quality following the addition of pesticide application. The objective of this work was to determine the impact of endosulfan, profenophos formulations on soil protease and urease activity.

\section{Materials and methods}

Soil. Black clay soil, collected from a fallow groundnut cultivated field of Kurnool district of Andhra Pradesh, to a depth of 0-12 centimeters, air dried and sifted through 2 millimeter sieve was stored at $4^{\circ} \mathrm{C}$ prior to analysis. Mineral matter of soil samples was obtained by following the method of Johnson and Ulrich 1960 . Soil $\mathrm{pH}$ was determined by using 1:1.25 soils to the water ratio in a systronic digital $\mathrm{pH}$ meter. Organic matter in soil samples was estimated by Walkley and Black method, the total nitrogen content in soil samples was determined by Micro-Kjeldhal method (Jackson 1971). Electrical conductivity was measured by a conductivity bridge and the contents of nitrite - nitrogen (Barnes and Folkard 1951) the contents of nitrate - nitrogen - by Brucine method (Ranney and Bartlett 1972). Important physicochemical properties of the black clay soil are presented in Table 1.
Table.1. Physicochemical characteristics of the soil

\begin{tabular}{|c|c|}
\hline Properties & $\begin{array}{c}\text { Black } \\
\text { clay soil }\end{array}$ \\
\hline Sand $(\%)$ & 61.7 \\
\hline Silt $(\%)$ & 15.2 \\
\hline Clay (\%) & 23.8 \\
\hline $\mathrm{pH}^{\mathrm{a}}$ & 7.4 \\
\hline Water holding capacity $\left(\mathrm{ml} \mathrm{g}^{-1}\right.$ soil) & 0.31 \\
\hline Electrical conductivity (m.mhos) & 260 \\
\hline Organic matter $^{\mathrm{b}}(\%)$ & 1.078 \\
\hline Total nitrogen ${ }^{\mathrm{c}}(\%)$ & 0.046 \\
\hline $\mathrm{NH}_{4}^{+}-\mathrm{N}\left(\mu \mathrm{g} \mathrm{g}^{-1}\right.$ soil $^{\mathrm{d}}$ & 8.97 \\
\hline $\mathrm{NO}_{2}{ }^{-}-\mathrm{N}\left(\mu \mathrm{gg}^{-1}\right.$ soil $^{\mathrm{e}}{ }^{\mathrm{s}}$ & 0.412 \\
\hline $\mathrm{NO}_{3}{ }^{-}-\mathrm{N}\left(\mu \mathrm{g} \mathrm{g}^{-1}\right.$ soil $^{f}{ }^{\mathrm{f}}$ & 1.340 \\
\hline
\end{tabular}

Where $a=1: 1.25=$ Soil: Water slurry $b=$ WalkleyBlack Method (Jackson, 1971) $c=$ Micro-Kjeldhal Method (Jackson, 1971) $d=$ Nesslerization method (Jackson, 1971) e =Diazotization Method (Barnes and Folkard, 1951) $f=$ Brucine Method (Ranney and Bartlett, 1972)

Insecticides. To determine the influence of selected insecticides on soil enzyme activities, endosulfan, an organochlorine insecticide (of 35\% emulsifying concentration), was obtained from Hoechstschering agro ero (Ltd). Gujarat and profenophos, an organophosphate (of 50\% emulsifying concentration), was obtained from Sudarsha industries Ltd, Pune 411001, India.

Protease and urease activity. To determine protease and urease activities one gram and two gram portion soil samples were distributed in test tubes (12 $\mathrm{x} 150 \mathrm{~mm}$ ) and treated with the selected insecticides to provide the final concentration of 1.0, 2.5, 5.0, 7.5 and $10.0 \mathrm{~kg} \mathrm{ha}^{-1}$ level. All the treatments including a control one were incubated in the laboratory at a room temperature $\left(28 \pm 4^{\circ} \mathrm{C}\right)$. After ten days of incubation, triplicate soil samples were withdrawn for the assay of protease earlier studied by Speir and Ross (1975); Rangaswamy and Venkateswarlu (1994). For the assay of urease by a phenol hypochlorite method (Fawcett and Scott, 1960); Rangaswamy and Venkateswarlu (1992a) adopted by Jaffer Mohiddin et al. (2011).

In another experiment, black clay soil samples in triplicates were treated with two insecticides, endosulfan and profenophos at 2.5 and $5.0 \mathrm{~kg} \mathrm{ha}^{-1}$. After incubation for 10, 20, 30 and 40 days at $28 \pm 4^{\circ}$ $\mathrm{C}$, triplicate soil samples were withdrawn to determine the rate of enzyme activity.

Assay of protease (EC 3.4.21.19). Untreated and insecticide- treated soil samples $(2 \mathrm{~g})$ were incubated for $24 \mathrm{~h}$ at $30^{\circ} \mathrm{C}$ with $10 \mathrm{ml}$ of $0.1 \mathrm{M}$ tris (2-amino-2 (hydroxymethylmethyl)-propane-1:3-diol, $\mathrm{pH}, \quad 7.5$ ) containing sodium caseinate $(2 \% \mathrm{w} / \mathrm{v})$ of trichloro, acetic acid was added and the mixer was centrifuged. A suitable aliquot of the supernatant was treated with $3 \mathrm{ml}$ of $1.4 \mathrm{M} \mathrm{Na}_{2} \mathrm{CO}_{3}$ followed by the addition of 1.0 $\mathrm{ml}$ Folin-Ciocalteu reagent $(33.3 \% \mathrm{v} / \mathrm{v})$. The intensity of blue color was read after $30 \mathrm{~min}$ at $700 \mathrm{~nm}$ in a spectrophotometer. Tyrosine was used as a standard. 
Assay of urease (E.C. 3.5.1.5). Urease activity in soil samples $(1 \mathrm{~g})$ was determined following the method of phenol hypochlorite (Fawcett and Scott, 1960). Untreated and insecticide- treated soil samples (1g) were mixed with $4 \mathrm{ml}$ of $0.1 \mathrm{M}$ sodium phosphate buffer at $\mathrm{pH}-7.0$ and $1 \mathrm{ml}$ of $1 \mathrm{M}$ urea solution and incubated for 30 minutes. After incubation, $10 \mathrm{ml}$ of $2 \mathrm{M} \mathrm{KCl}$ were added and the mixtures were kept at $4^{\circ} \mathrm{C}$ for $10 \mathrm{~min}$, to stop the enzymatic reaction. Suspensions were centrifuged for $5 \mathrm{~min}$. Two $\mathrm{ml}$ of supernatant was mixed with $5 \mathrm{ml}$ of phenol sodium nitroprusside solution and $5 \mathrm{ml}$ of 0.02 $\mathrm{M}$ sodium hypochlorite, and the mixture was incubated for 30 minutes in the dark, and the blue color formed was read at $630 \mathrm{~nm}$ in a spectrophotometer.

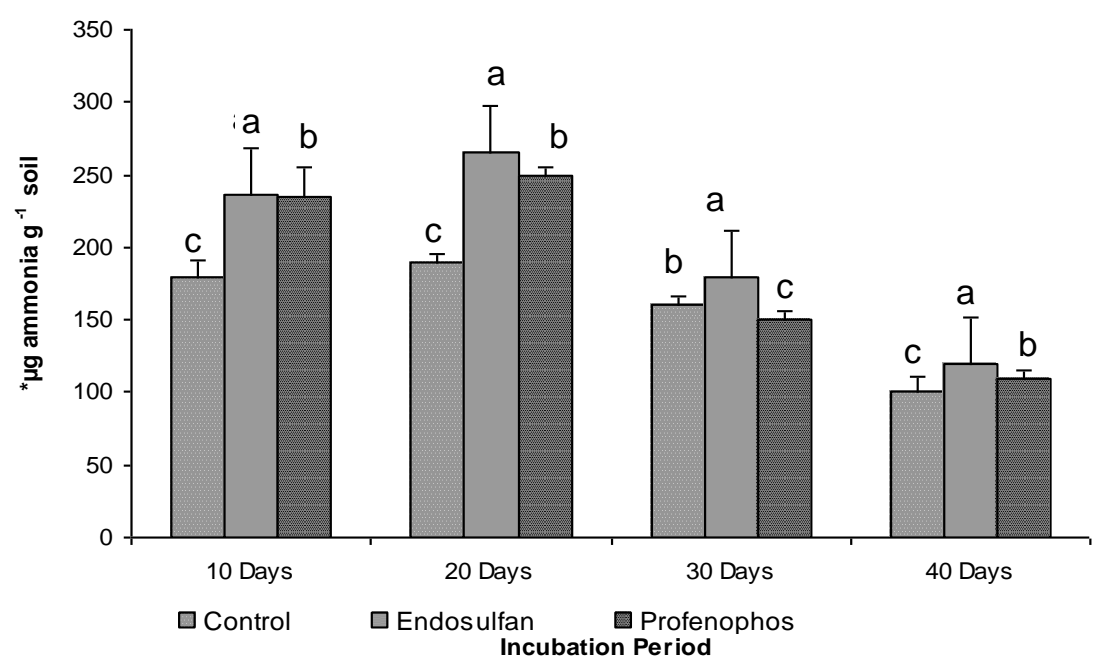

Fig.1. Influence of insecticdes at $\left(2.5 \mathrm{~kg} \mathrm{ha}^{-1}\right)$ on protease*activity in black clay soil incubated for 24 hours with $1 \%$ casein after 10,20, 30 and 40 days. The values are the means \pm S.E.., for each incubation periods, in each column followed by the same letter are significantly Different $(P \leq 0.05)$ from each other according to Duncan's Multiple Range (DMR) test

\section{Statistical analysis}

Table 2. Activity of protease under the impact of different concentrations of selected pesticides endosulfan and profenophos in black clay soil for 24 hours after 10 days

\begin{tabular}{||c|c|c||}
\hline \multirow{2}{*}{$\begin{array}{c}\text { Conc., of } \\
\text { insecticides } \\
\left(\mathrm{kg} \mathrm{ha}^{-1}\right)\end{array}$} & \multicolumn{2}{|c|}{ Black clay soil } \\
\cline { 2 - 3 } & Endosulfan & Profenophos \\
\hline 0.0 & $602 \pm 1.154^{\mathrm{d}}$ & $602 \pm 1.154^{\mathrm{d}}$ \\
& $(100)$ & $(100)$ \\
\hline 1.0 & $680 \pm 5.773^{\mathrm{c}}$ & $613 \pm 1.732^{\mathrm{c}}$ \\
& $(113)$ & $(102)$ \\
\hline 2.5 & $883 \pm 5.773^{\mathrm{a}}$ & $692 \pm 5.773^{\mathrm{a}}$ \\
& $(147)$ & $(115)$ \\
\hline 5.0 & $750 \pm 5.773^{\mathrm{b}}$ & $630 \pm 17.320^{\mathrm{b}}$ \\
& $(124)$ & $(105)$ \\
\hline 7.5 & $748 \pm 1.154^{\mathrm{b}}$ & $612 \pm 1.154^{\mathrm{c}}$ \\
& $(124)$ & $(102)$ \\
\hline 10.0 & $542 \pm 1.154^{\mathrm{e}}$ & $544 \pm 2.309^{\mathrm{e}}$ \\
& $(90)$ & $(90)$ \\
\hline
\end{tabular}

* $\mu g$ glucose per gram soil formed after 24 hrs with $1 \%$ casein.. Figures in parentheses indicate relative production percentages. In each column means followed by the same letter are not significantly different $(P \leq 0.05)$ from each other according to Duncan's Multiple Range (DMR) test.

The activity of the protease and urease was calculated on the basis of soil weight (oven dried). Data were analyzed using one-way ANOVA and the differences contrasted - using Duncan's multiple range test (DMRT) (Megharaj et al. 1999; Jaffer et al. 2011). All statistical analysis was performed at $(\mathrm{P} \leq$ 0.05) using the SPSS statistical software package.

Table 3. Activity of urease* under the impact of different concentrations of selected pesticides endosulfan and profenophos in black clay soil for 24 hours after 10 days

\begin{tabular}{|c|c|c|}
\hline \multirow{2}{*}{$\begin{array}{c}\text { Conc., of } \\
\text { insecticides } \\
\left(\mathrm{kg} \mathrm{ha}^{-1}\right)\end{array}$} & \multicolumn{2}{|c|}{ Black clay soil } \\
\cline { 2 - 3 } & Endosulfan & Profenophos \\
\hline 0.0 & $\begin{array}{c}180 \pm 5.773^{\mathrm{d}} \\
(100)\end{array}$ & $\begin{array}{c}180 \pm 5.773^{\mathrm{d}} \\
(100)\end{array}$ \\
\hline 1.0 & $192 \pm 5.773^{\mathrm{c}}$ & $180 \pm 5.773^{\mathrm{d}}$ \\
& $(107)$ & $(100)$ \\
\hline 2.5 & $223 \pm 1.732^{\mathrm{b}}$ & $202 \pm 1.154^{\mathrm{b}}$ \\
& $(124)$ & $(112)$ \\
\hline 5.0 & $236 \pm 17.320^{\mathrm{a}}$ & $235 \pm 20.207^{\mathrm{a}}$ \\
& $(131)$ & $(130)$ \\
\hline 7.5 & $196 \pm 2.309^{\mathrm{c}}$ & $192 \pm 1.154^{\mathrm{c}}$ \\
& $(109)$ & $(107)$ \\
\hline 10.0 & $154 \pm 2.309^{\mathrm{e}}$ & $152 \pm 1.154^{\mathrm{e}}$ \\
& $(85)$ & $(84)$ \\
\hline
\end{tabular}

* $\mu$ glucose per gram soil formed after 24 and $72 \mathrm{hrs}$ incubation with $2 \%$ starch.

Figures in parentheses indicate relative production percentages.

In each column means followed by the same letter are not significantly different $(P \leq 0.05)$ from each other according to Duncan's Multiple Range (DMR) test. 


\section{Results}

Our investigation has revealed that protease activity has more drastically decreased at higher concentrations $\left(5.0,7.510 .0 \mathrm{~kg} \mathrm{ha}^{-1}\right)$ of endosulfan and profenophos treated soils than the untreated controls throughout the experiment (Table 2), suggesting that the enzyme is rather sensitive to endosulfan and profenophos. Interestingly, a stimulatory effect was observed at $10-25 \mathrm{ppm}$ concentrations with individual increments of two insecticidal treatments, on the control, they are as follows: $13-47 \%$ and $2-15 \%$ in black clay soil after
10 days of incubation. This trend follows up to 20 days of incubation, when further prolonged in the period of incubation up to 40 days, a decline in enzyme activity was observed. Similar to protease, urease also follows the same trend, a stimulatory effect of endosulfan and profenophos was observed at 10-50 ppm concentrations with individual increments of two insecticidal treatments on the control, they were $7-31 \%$ and $12-30 \%$ in black clay soil after 10 days of incubation (Table 3). Urease activity decreased significantly after a longer period of incubation up to 30 or 40 days (Fig. 2).

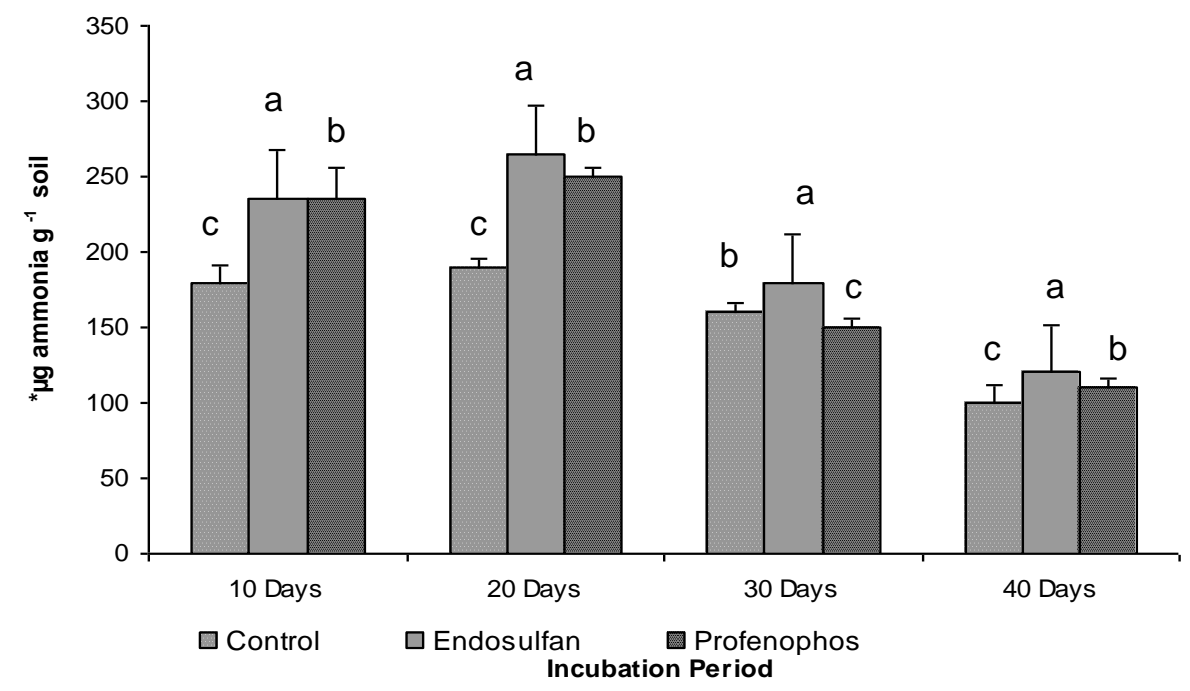

Fig. 2. Influence of insecticides at $5.0 \mathrm{~kg} \mathrm{ha}{ }^{-1}$ on urease* activity in black soil after 30 min incubation at $37^{\circ} \mathrm{C}$ with urea * $\mu \mathrm{g}$ ammonia per gram soil formed after 30 min incubation at $37^{\circ} \mathrm{C}$ with urea. The values are the means $\pm \mathrm{S} . \mathrm{E} . .$, for each incubation periods, in each column followed by the same letter they are significantly different $(P \leq 0.05)$ from each other according to Duncan's Multiple Range (DMR) test.

\section{Discussion}

The laterite and vertisol soils were predominantly used for the cultivation of groundnut (Arachis hypogeae L.) in Kurnool district of Andhra Pradesh, India. The major constraint in groundnut crop is insects and pathogenic fungi. Hence, pesticides were frequently used for crop protection. Due to continuous use of these pesticides, persistence of pesticide residues in the soil may have a significant impact on soil microbial communities and their functions, such as the activity of enzymes which are directly related to soil health and fertility and also to the removal of contaminants (Ingham et al. 1991, Beare et al. 1992). In general, the organic matter content is higher in black soil than in red soil. Hence, black soil is selected to study the effect of insecticides on the protease and urease activities (Srinivasulu et al. 2011). Our reports are in agreement with the previous studies carried out by Srinivasulu et al. (2010b) whose observed activity of protease was higher in black soil and received the monocrotophos and chlorpyrifos in combination with mancozeb and carbendazim, respectively, at $5.0 \mathrm{~kg} \mathrm{ha}^{-1}$ incubated for 20 days. This increase in enzyme activity continued up to 20 days of incubation and afterwards there was a turn down in enzyme activity. Rasool and Reshi (2010) noticed the stimulatory effect on protease activity in comparison with the control up to 21 days of incubation. Similar observations on protease activity in soil treated with monocrototphos, quinolphos, cypermethrin and fenvalerate up to $25 \mathrm{ppm}$ level was recorded by Rangaswamy et al. (1994). The same results were observed by Endo et al. (1982). The stimulation of protease activity in a native soil was reported after its treatment with Linuron at $10 \mathrm{mg} \mathrm{kg}^{-1}$, where as Cartap-HCL at $100-1000 \mathrm{mg} \mathrm{kg}^{-1}$ inhibited the enzyme activity without recovery during the period of 60 days. On the other hand, several reports indicate that protease activity in soils was individually inhibited by the application of urea at $200-\mathrm{N} \mathrm{kg} \mathrm{ha}^{-1}$ and of herbicides dalapon and paraquat at $10 \mathrm{~kg} \mathrm{ha}^{-1}$ by 13 and $18 \%$, respectively. The combination of urea and herbicides at the same concentrations reduced the protease activity in soils by $41-56 \%$ indicating the synergistic interaction at the end of the 10-day incubation (Namdeo and Dube, 1973), In contrast, thiram at $10 \mathrm{ppm}$ decreased urease activity in both sandy and organic soils after 7 days (Tu 1990). Gooty Jaffer Mohiddin et al. (2011) noticed that two 
insecticides, acephate and imidacloprid at 10, 25, 50 $\mu \mathrm{g} \mathrm{g}^{-1}$ levels, individually caused increments of 30-77 and $46-54 \%$ increase in urease activity on the control in black soil at a 10-day interval, respectively. The enzyme activity decreased significantly in a longer period of incubation up to 30 and 40 days. A similar trend was observed by Srinivasulu et al. (2010a) with tridemorph and captan which showed individual increments of 28.37-93.70 and $18.32-90.37 \%$ increase in urease activity over the control, respectively, in black soil at 10-day interval. According to Gianfreda et al. (1994), glyphosate enhanced urease activity of soils 1.1-1.4-fold and of soil extracts 2.59 to 6.73 -fold at 0.3 and $1.5 \mathrm{mM}$, but had no influence on free or immobilized jackbean (Canavalia ensiformis) urease. In contrast, Rasool and Reshi (2010) reported a significant decrease in urease activity with mancozeb at different application rates over the control. In another study, urease activity was not inhibited by fenamiphos (Caceres et al. 2009) in Australian and Ecuadorean soils. On the other hand, urease activity was inhibited by napropamide at all concentrations relative to the control with long periods of application (Guo et al. 2008). Similarly, Cycon et al. (2010) noticed that urease activity declined in sandy loam and loamy sand soils with a combination (mancozeb + dimethomorph) at higher concentrations compared to the control. Similarly, urease activity decreased by $20 \%$ in unamended polluted soils (with MCPA) (Tejda et al. 2010) following the exposure to chlorpyrifos (CPF) and its oxon derivative (CPO) at higher concentrations (Wang et al. 2010). In another study a $55.6 \%$ decrease in urease enzyme activity was noticed with different concentrations $(0,200$, 400,600, 800, and $1000 \mathrm{mg} \mathrm{kg}^{-1}$ ) of Pb-contaminated soil (Akmal and $\mathrm{Xu}$ 2008). In contrast, Rahmansyah et al. (2009) reported an increase in urease enzyme activity after 2 weeks of incubation which declined after 12 weeks of incubation with insecticide deltamethrin and fungicide probineb. In another study, urease activity was not affected by the presence of glyphosate at $5.4 \mathrm{~kg} \mathrm{ha}^{-1}$ in soil (Davies and Greaves 1981).

\section{Conclusions}

The results of the present study have clearly indicated that the insecticides endosulfan and profenophos profoundly enhance the activities of both protease and urease when used 2.0-5.0 kg ha- ${ }^{-1}$. Thereby, proteases promote a breakdown of proteinaceous substance and urease promotes hydrolysis of urea to $\mathrm{NH}^{+}$in soil to simpler nitrogen compounds that are available for plant nutrition, and in turn, the plant yield will be good which is beneficial to the farmer and the society. Based on the above results, it is concluded that the protease and urease are not affected by the insecticides applied at the recommended levels to the agricultural system. Very little information is available on the influence of endosulfan and profenophos on protease and urease activities in groundnut soils. Hence, further research is needed to evaluate the effect of these insecticides on soil enzyme activities.

\section{Acknoledgements}

We are grateful to the Sri Krishnadevaraya University authorities and highly thankful to Department of Microbiology for providing necessary facilities throughout our research work.

\section{References}

AKMAL M., XU J-M., 2008: Dehydrogenase, urease and phosphatase activities as affected by $\mathrm{Pb}$ contamination in the soil. Soil and Environment vol. 27 (2), pp. 139-142.

ANDRÉA., M. M., PERES, T. B., LUCHINI, L. C., PETTINELLI JUNIOR., A., 2000: Impact of long-term pesticide application on some soil biological parameters. Journal of Environmental Science and Health, New York, v. B35, pp. 297-307.

BARNES H., FOLKARD BR., 1951: The determinati on of nitrite. Analyst 76, pp.599. http://dx.doi.org/10.1039/an9517600599

BAXTER J., CUMMINGS SP., 2008: The degradation of the herbicide bromoxynil and its impact on bacterial diversity in a top soil. Journal of Applied Microbiology vol. 104, pp. 1605-1616. http://dx.doi.org/10.1111/j.1365-2672.2007.03709.x

BEARE MH., PERMELLE RW., HENDRIX PF., CHENG W., 1992: Microbial and faunal interactions and effects on litter nitrogen \& decomposition in agrosystems. Ecological Monographs vol. 62, pp.569-591.

CACERES TP., HE W-X., MEGHARAJ M., NAIDU R., 2009: Effect of insecticide fenamiphos on soil microbial activities in Australian and Ecuadorean soils. Journal of Environmental Science and Health Part B vol. 44, pp.1317. http://dx.doi.org/10.1080/03601230802519504

CARRIGER J F., G. M., GARDINALI, P. R., PERRY, W. B., TOMPKINS, M. S., and FERNANDEZ, A. M., 2006: Pesticides of potential ecological concern in sediment from South Florida Canals: An ecological risk prioritization for aquatic arthropods. Soil Sediment.Contamination. vol. 15, pp. 21-45. http://dx.doi.org/10.1080/15320380500363095

CYCON M., PIOTROWSKA-SEGET Z., KOZDROJ J., 2010: Response of indigenous microorganisms to a fungicidal mixture of mancozeb and dimethomorph added to sandy soils. International Biodeteroration and Biodegradation vol. 64, pp.316-323. http://dx.doi.org/10.1016/j.ibiod.2010.03.006

DAVIES HA, GREAVES MP., 1981: Effects of some herbicides on soil enzyme activities. Weed Research vol. 21 , pp. 205-209. http://dx.doi.org/10.1111/j.13653180.1981.tb00119.x

ENDO T., K. TAIKI T. NOBUTSURA and MICHIHIKO S., 1982: Effect of insecticide cartaphydrochloride on soil enzyme activities, respiration and on nitrification. Journal Pesticide Science vol. 7, pp. 101-110. http://dx.doi.org/10.1584/jpestics.7.101

ENGELEN B., MEINKEN K., VON WINTZINGERODE F., HEUER H., MALKOMES H-P., BACKHAUS H., 1998. Monitoring impact of a pesticide treatment on bacterial soil communities by metabolic and geneticfingerprinting in addition to conventional testing 
procedures. Applied Environment Microbiology vol. 64, pp. $2814-2821$

FAO., 2004: Food and Agricultural Organization of the United States. Production yearbook, vol. 51(142), pp.104-5.

FAWCETT JK., SCOTT JE., 1960: A rapid and precise method for the determination of urea. Journal of Clinical Pathology vol. 13, , pp. 156-159. http://dx.doi.org/10.1136/jcp.13.2.156

GIANFREDA L., SANNINO F., ORTEGA N., NANNIP IERI P., 1994: Activity of free and immobilized urease in soil. Effects of pesticides. Soil Biology and Biochemistry vol. 26, pp.777-784. http://dx.doi.org/10.1016/0038-0717(94)90273-9

GIRADDI RS., LINGAPPA S., and RAJENDRA HEGDE., 1999: Bioefficacy of new wettable powders on leaf eating caterpillars of groundnut. Pestol. Vol. 23(7), pp. 57-59.

GOOTY JAFFER MOHIDDIN., MANDALA SRINI VASULU., MEKAPOGU MADAKKA., KONDERI SUBR AMANYAM., and VENGATAMPALLI

RANGASWAMY., 2011: Influence of selected Insecticides on Enzyme Activities in Groundnut (Arachis hypogeae L.) Soils. Dynamic Soil Dynami Plant. volume 5 special issue( 1): 65-69.

GUO H., CHEN G-F., LU Z-P., ZHAO H., YANG H., 2008: Alteration of microbial properties and community structure in soils exposed to napropamide. Journal of Environmental Science vol. 21, pp.494-502. http://dx.doi.org/10.1016/S1001-0742(08)62298-6

INGHAM ER., PARAMELLE R., COLEMAN DC., CROSSELY DA., 1991: Reduction of microbial \& faunal groups following application of streptomycin \& captan in Georgia no tillage agroecosystems. Pedobiologia vol. 35 , pp.297-304.

JACKSON ML., 1971: Soil Chem. Anal. Prentice Hall India, New Delhi.

JAFFERMOHIDDIN G., SRINIVASULU M., MAD AKKA M., and RANGASWAMY V., 2010: Influence of insecticides on the activity of amylase and cellulase in groundnut (Arachis hypogea L.) soil, Ecology Environment \& Conservation. vol. 16 (3), pp. 383-388.

JAYASHREE R., VASUDEVAN N., 2007: Persistence and distribution of endosulfan under field condition. Environ Monitoring Assessment vol. 131, pp. 475-87. http://dx.doi.org/10.1007/s10661-006-9493-1

JOHNSON CM., ULRICH A., 1960: Determination of moisture in plant tissues. California Agriculture Bulletin 766, pp.112-115.

KORI RN., PATIL SL., SALAKINAKOP SR., HUNSHAL CS., and NAGAGOUDA BT., 2002: Economics of integrated pest management in irrigated groundnut. J. Oil.Seeds.Res., 17(1): pp 61-65.

KWON GS., KIM JE., KIM TK., SOHN HY., KOH SC., SHIN KS., KIM DG., 2002: Klebsiella pneumoniae KE0-1 degrades endosulfan without formation of the toxic metabolite endosulfan sulfate. FEMS Microbiology Letter vol. 215,, pp. 255-259. http://dx.doi.org/10.1111/j.15746968.2002.tb11399.x

LIU J., XIE J., CHU Y., SUN C., CHEN C., and WANG Q., 2008: Combined effect of cypermethrin and copper on catalase activity in soil. Journal Soils Sediments 8, pp.327-332. http://dx.doi.org/10.1007/s11368-008-0029$\mathrm{X}$

MADHUN., Y. A., and FREED., V. H., 1990: Impact of pesticides on the environment, In: Pesticides in the Soil Environment: Processes, Impacts, and Modeling, Cheng, $\mathrm{H}$. H., (Ed. SSSA Book Series No. 2), 429-466, Soil Science Society of America.
MEGHARAJ M., SINGLETON I., KOOKANA R., NAIDU R., 1999: Persistence and effects of fenamiphos on native algal populations and enzymatic activities in soil. Soil Biology and Biochemistry vol. 31 , pp.1549-1553. http://dx.doi.org/10.1016/S0038-0717(99)00078-4

MEKAPOGU MADAKKA., MANDALA SRINIVAS ULU.,GOOTY JAFFER MOHIDDIN., and VENGATAMP ALLI RANGASWAMY., 2011: Effect of pesticides on microbial diversity and urease in Groundnut (Arachis hypogeae L.) Soil. Dynamic Soil Dynami Plant. (IN PRESS).

NAMDEO K.N., and DUBE. J.N., 1973: Residual effect of urea and herbicides on hexosamine content and urease and proteinase activities in a grassland soil. Soil Biology and Biochemistry vol. 5 , pp.855-859. http://dx.doi.org/10.1016/0038-0717(73)90031-X

PIMENTEL D., 1995: Amounts of pesticides reaching target pests: Environmental impacts and ethics. Journal Agriculture Environment Ethics vol. 8, pp. 17-29. http://dx.doi.org/10.1007/BF02286399

RAHMANSYAH M., ANTONIUS S., SULISTINAH N., 2009: phosphatase and urease instability caused by pesticides present in soil improved by grounded rice straw. ARPN Journal of Agricultural and Biological Science vol. 4 (2), pp.56-62.

RANGASWAMY V., and VENKATESWARLU K.., 1992a: Activities of amylase and invertase as influenced by the application of monocrotophos, quinalphos, cypermethrin and fenvalerate to groundnut soils. Chemosphere, vol. 25(4) pp.525-530. http://dx.doi.org/10.1016/00456535(92)90284-X

RANGASWAMY V., REDDY BR., AND VENKATESWARLU K., 1994. Activities of dehydrogenase and protease in soil as influenced by monocrotophos, quinalphos, cypermethrin fenvalerate. Agriculture Ecosystem Environment vol. 47, pp. 319-326. http://dx.doi.org/10.1016/0167-8809(94)90098-1

RANGASWAMY V., VENKATESWARLU K., 1992: Activities of amylase and invertase as influenced by the application of monocrotophos, quinalphos, cypermethrin and fenvalerate to groundnut soil. Chemosphere vol. 25, pp. 525-530. http://dx.doi.org/10.1016/0045-6535(92)90284-X

RANNEY TA., BARTLETT RJ., 1972: Rapid field determination of nitrate in natural waters. Communications in Soil Science and Plant Analysis vol. 3, pp.183-186. http://dx.doi.org/10.1080/00103627209366366

RASOOL N., ZAFAR RESHI A., 2010: Effect of the fungicide mancozeb at different application rates on enzyme activities in a silt loam soil of the Kashmir Himalaya, India. Tropical Ecology vol. 51, pp. 199-205.

ROMEH AA., MEKKY TM., RAMADAN RA., HENDAWI MY., 2009: Dissipation of Profenophos, Imidacloprid and Propiconazole in Tomato Fruits and Products. Bull Environment Contam Toxicology. Vol. 83(6), pp. 812-7. http://dx.doi.org/10.1007/s00128-0099852-z

SPEIR TW., and DJ., ROSS., 1975: Effects of storage on the activities of protease, urease, phosphatase and sulphatase in three soils under pasture. New Zealand Journal Science. vol. 18, pp. 231-237.

SRINIVASULU M., JAFFER MOHIDDIN G., MADAKKA M., RANGASWAMY V., 2010a: Phosphatase and urease activity in groundnut soils as influenced by the selected fungicides. Asian Journal of Microbiology, Biotechnology and Environmental Sciences vol. 12, pp. 141-146.

SRINIVASULU M., MADAKKA M., JAFFER MOHIDDIN G., RANGASWAMY V., 2010b: Effect of Monocrotophos, chloropyriphos alone and in combination 
with mancozeb and carbendazim on urease activity in groundnut (Arachis hypogaeaL.) soils. Ecology, Environment and Conservation vol. 16, pp. 89-94.

SRINIVASULU M., JAFFER MOHIDDIN G., RANGASWAMY V., 2011: Effect of insecticides alone and in combination with fungicides on nitrification and phosphatase activity in two groundnut (Arachis hypogeae L.) soils. Environmental Geochemistry and Health http://dx.doi.org/10.1007/s10653-011-9399-x

TALAWAR S., 2004: Peanut in India: History, Production and Utilization. Peanut in local and global food system series report No.5. Department of Anthropology, University of Georgia.

TEJADA M., GARCIA-MARTINEZ AM., GOMEZ I., PARRADO J., 2010: Application of MCPA herbicide on soils amended with biostimulants: Short-time effects on soil biological properties. Chemosphere vol.80, pp.1088-1094. http://dx.doi.org/10.1016/j.chemosphere.2010.04.074

TOPP E., VALLAEYS T., and SOULAS G., 1997: Pesticides: Microbial degradation and effects on microorganisms. In "Modern Soil Microbiology" (J. D. van Elsas, J. T. Trevors, and E. M. H. Wellington, Eds.), 547-575 pp. Marcel Dekker, New York.

TU CM., 1990: Effect of four experimental insecticides on enzyme activities and levels of adenosine in mineral and organic soils. Journal of Environmental Science and Health vol. 25, pp.787-800. http://dx.doi.org/10.1080/03601239009372719

VIJAY GUNDI AKB., VISWANATH B., SUBHOSH CHANDRA M., NARAHARI KUMAR V., RAJASEKHAR REDDY B., 2007: Activities of cellulose and amylase in soils as influenced by insecticide interactions. Ecotoxicology and Environmental Safety vol. $68,278-285$, pp.

WANG F., YAO J., CHEN H-L., CHEN K., TREBSE P., ZARAY G., 2010: Comparative toxicity of chlorpyrifos and its oxon derivatives to soil microbial activity by combined methods. Chemosphere vol. 78, pp. 319-326. http://dx.doi.org/10.1016/j.chemosphere.2009.10.030
C. Nasreen, MP hil., Sri Krishnadevaraya University, Research Scholar.

Main research area: Bioremediation

E-mail: nasreen@gmail.com

G. Jaffer Mohiddin, MPhil., Ph.D., Sri Krishnadevaraya University, UGC-SAP Project Fellow.

Main research area: Bioremediation

E-mail: jaffermicro@gmail.com

M. Srinivasulu, MPhil., Ph.D., Sri Krishnadevaraya University, UGC-MRP Fellow.

Main research area: Bioremediation

E-mail: seenmahi452@gmail.com

A. Rekha Padmini MPhil., Sri Krishnadevaraya University, Research Scholar.

Main research area: Bioremediation

E-mail: rekha.mannepula@gmail.com

P. Ramanamma, MPhil., Sri Krishnadevaraya University, Research Scholar.

Main research area: Bioremediation

E-mail: rama.ramamsc@gmail.com

V. Rangaswamy, MPhil., B.ED., and Ph.D. Sri Krishnadevaraya University, Professor in Microbiology Department.

Main research area: Bioremediation

E-mail: rangamanjula@yahoo.com 


\title{
Insekticidų poveikis juodojo molio fermento aktyvumui laukuose, kuriuose auginami žemès riešutai (Arachis Hypogaea L.)
}

\author{
C. Nasreen, G. Jaffer Mohiddin, M. Srinivasulu A. Rekha Padmini, \\ P. Ramanamma, V. Rangaswamy \\ ${ }^{1}$ Mikrobiologijos katedra, Sri Krishnadevaraya universitetas, Indija
}

(gauta 2011 m. lapkričio mèn., priimta spaudai 2012m. birželio mèn.)

\begin{abstract}
Pesticidai plačiai naudojami žemès ūkyje kaip viena iš kenkèjų naikinimo priemonių. Straipsnyje aprašomas tyrimas, kuri atliekant buvo vertinama dviejų insekticidų - endosulfano (organinio chloro) ir profenofoso (organinio fosfato) - poveikis peptidazei (tirozinas susiformavęs iš kazeino) ir ureazei (iš šlapalo išsiskyręs amoniakas) dirvoje. Mèginiai buvo imti iš pūdymui palikto žemės riešutų lauko, kuriame buvo naudojami iprasti insekticidų kiekiai. Laboratoriškai buvo tirta didesnè insekticidu koncentracija $\left(1,0 ; 2,5 ; 5,0 ; 7,5 ; 10,0 \mathrm{~kg} \mathrm{ha}^{-1}\right)$. Rezultatai parodè stiprų proteazès ir ureazès fermentų aktyvumą dirvoje, kur insekticidų koncentracija sausoje dirvoje buvo lygi 2,5 ir $5,0 \mathrm{~kg} \mathrm{ha}^{-1}$. Išdirbus žemę, po 24 valandų inkubacinio periodo proteazès aktyvumas reikšmingai padidèjo, ureazès aktyvumas sumažèjo. Tačiau abiejų fermentų aktyvumas gerokai sumažèjo tik po 30 ir 40 dienų inkubacinio periodo.
\end{abstract}

